Ann. Phytopath. Soc. Japan XXX, (4) : 186 191 (1965)

\title{
Ecologic and taxonomic studies on Pythium as pathogenic soil fungi.
}

VI. Some species of Pythium causing rhizome rot of Hindu lotus.

\author{
Minoru TAKahashi*, Akira OHUCHI**, and \\ Romeo V. Alicbusan***
}

Hindu lotus (Nelumbo nucifera Gaertn.) is being cultivated in different parts of the country notably in Aichi, Saga, Osaka, Fukuoka, Ibaragi, Tokyo, Tokushima, Yamaguchi, Okayama, Shizuoka, Nagasaki, and Kagawa prefectures for so long a time. This plant grows well in some restricted places which are unsuitable for rice culture.

The rhizome rot of lotus was first studied as early as 1907 by Hori ${ }^{6}$, and a bacterium was isolated and identified as Bacillus nelumbii Uyeda. Ikata ${ }^{7}$ ) isolated Fusarium species and attributed the disease to be caused by the fungus. Nishikado and Watanabe ${ }^{11)}$ identified Fusarium bulbigenum Cke. and Mass. var. nelumbicolum Nishikado and Watanabe as the causal organism of the rhizome rot. Nishizawa ${ }^{14,15}$ ) published a detailed study about the disease and classified the disease type of infected lotus. He reported that the disease was caused by several Fusarium and Pythium species and that the morphology, pathogenicity of the fungi and their relationships with the associating microorganisms were described. Nishikado and Watanabe ${ }^{12,13)}$ and Nakazawa and Kato ${ }^{10)}$ also conducted studies on the ecology of Fusarium species. Saga ${ }^{18)}$ and Okayama Agricultural Experiment Station ${ }^{17)}$ and Nishizawa ${ }^{16)}$ studied the control measures.

It has been established that Pythium as well as Fusarium is able to attack lotus but many works have not reported the identification and taxonomy of the Pythium.

At the request of the Department of Agriculture and Forestry, Osaka Prefectural Office, a study on the identification, classificantion and ecology of the Pythium isolated from the diseased lotus was conducted. Some of the species of Pythium were obtained from Tokushima Agricultural Experiment Station and the others were isolated from diseased plants collected from the suburbs of Naruto City and Kadoma City, and Moriguchi City, Osaka prefecture.

The primary purpose of the present paper is to report the identification and classification of several species of Pythium causing rhizome rot of lotus.

\section{Materials and Methods}

The diseased plants were washed thoroughly with tap water and then disinfected in $\mathrm{HgCl}_{2}$ (1:2000) for 2 minutes. Washed with 3 changes of distilled water and then pieces of diseased tissue were cut with sterile scalpel. The sections were placed on the culture medium in Petridishes. Several species of Pythium were isolated selectively with the following methods that are usually used in our laboratory.

Selective isoltion of Pythium from bacterial contaminants: Corn-meal agar containing $50 \mathrm{ppm}$ of either streptomycin, terramycin and penicillin and $20 \mathrm{ppm}$ of kanamycin slowed down the growth of Pythium but completely inhibits bacterial growth. Combinations of these antibiotics

\footnotetext{
* Laboratory of Plant Pathology, University of Osaka Prefecture.

** Laboratory of Plant Pathology, National Institute of Agricultural Sciences.

*** Department of Plant Pathology, University of the Philippines.

Note: This study was partially supported by the Special Research Grant of the Teehnical Conference of Agriculture, Forestry and Fishery of the Ministry of Agrículture and Forestry.
} 
at the same level of concentrations broadens the spectrum and more species of contaminating bacteria could be eliminated.

Selective culture medium for the isolation of Pythium: It is quite difficult to isolate Pythium selectively from contaminating bacteria and other soil fungi by the method described above. Pythium aphanidermatum, P. ultimum and other species of Pythium can be isolated from Fusarium, Rhizotconia, Trichoderma and bacteria by using corn-meal agar with $1000 \mathrm{ppm}$ penicillin and $50 \mathrm{ppm}$ of streptomycin otherwise referred to as CMA-P1000-S50 agar. A modified procedure of isolation was also fou $d$ to be effective. Aside from the addition of antibiotics to the culture medium, the differences in growth rate among the fungi can sometimes be put to advantage in isolation.

Four pieces or sections sliced from the disinfected diseased stem were placed on corn-meal

Table 1. The optimum temperature for mycelial growth of Pythium (mm.)*

\begin{tabular}{|c|c|c|c|c|c|c|c|c|c|c|c|c|c|c|}
\hline \multirow{2}{*}{$\begin{array}{l}\text { Culture } \\
\text { No. }\end{array}$} & \multirow{2}{*}{ Pythium species } & \multirow{2}{*}{ Source } & \multicolumn{12}{|c|}{ Temperature $\left({ }^{\circ} \mathrm{C}.\right)$} \\
\hline & & & $\begin{array}{l}6 \\
\sim 9\end{array}$ & $12 \sim$ & 16 & 20 & 24 & 26 & 28 & 30 & 32 & 34 & 36 & 40 \\
\hline 0 & P. ultimum & $\begin{array}{l}\text { Hibiscus manihot } \\
\text { (seedling) }\end{array}$ & 0 & 15 & 29 & 42 & 56 & - & 61 & 60 & - & - & 14 & 0 \\
\hline 19 & P. aphanidermatum & $\begin{array}{l}\text { Cucumis sativus } \\
\text { (seedling) }\end{array}$ & 0 & 18 & - & 37 & 34 & - & 54 & 70 & 78 & - & 82 & - \\
\hline 12 & $"$ & $\begin{array}{l}\text { Cucumis sativus } \\
\text { (fruit) }\end{array}$ & - & 0 & 0 & 13 & 30 & 一 & 62 & 68 & 74 & 77 & 80 & 67 \\
\hline 3 & P. debaryanum & $\begin{array}{l}\text { Cucumis sativus } \\
\text { (seedling) }\end{array}$ & 0 & 16 & 23 & 30 & 50 & 一 & 68 & 74 & 68 & 58 & 28 & 0 \\
\hline 23 & P. cucurbitacearum & " " " & - & 16 & - & 27 & - & 47 & 一 & 50 & - & 16 & - & 0 \\
\hline 26 & P. aphanidermatum & Water & - & 0 & 15 & 30 & 36 & - & 60 & 67 & 72 & 74 & 78 & 65 \\
\hline 2 & P. hemmianum & $\begin{array}{l}\text { Luffa cylindrica } \\
\text { (seedling) }\end{array}$ & - & 52 & - & 72 & 84 & - & 86 & 94 & 73 & - & 0 & - \\
\hline 21 & P. zingiberum & $\begin{array}{l}\text { Zingiber officinale } \\
\text { (rhizome) }\end{array}$ & 一 & 0 & - & 23 & 51 & - & 57 & 89 & 94 & - & 91 & - \\
\hline 7 & P. vexans & $\begin{array}{l}\text { Lycopersicon escu- } \\
\text { lentum (seedling) }\end{array}$ & 17 & - & - & 23 & 35 & - & 42 & 46 & 46 & - & 42 & - \\
\hline 22 & P. debaryanum & $\begin{array}{l}\text { Citrullus battich } \\
\quad \text { (seedling) }\end{array}$ & 0 & 10 & 27 & 36 & 41 & 48 & 62 & 59 & 58 & 52 & 21 & 0 \\
\hline
\end{tabular}

* Diameter of mycelial growth on corn-meal agar plate.

Table 2. The optimum temperature for the formation of oospores and conidia*

\begin{tabular}{c|c|c|c|c|c|c}
\hline \hline \multirow{2}{*}{$\begin{array}{c}\text { Temperature } \\
\left({ }^{\circ} \mathrm{C} .\right)\end{array}$} & \multicolumn{2}{|c|}{ Pythium ultimum } & \multicolumn{2}{|c|}{ Pythium debaryanum } & \multicolumn{2}{|c}{ Pythium sp**. } \\
\cline { 2 - 7 } & $\begin{array}{c}\text { Oospores } \\
(\%)\end{array}$ & $\begin{array}{c}\text { Conidia } \\
(\%)\end{array}$ & $\begin{array}{c}\text { Oospores } \\
(\%)\end{array}$ & $\begin{array}{c}\text { Conidia } \\
(\%)\end{array}$ & $\begin{array}{c}\text { Oospores } \\
(\%)\end{array}$ & $\begin{array}{c}\text { Conidia } \\
(\%)\end{array}$ \\
\hline $10-12$ & 85.7 & 14.3 & 90.0 & 10.0 & - & - \\
20 & 90.0 & 10.0 & 93.3 & 6.4 & 90.3 & 10.0 \\
24 & 65.0 & 35.0 & 90.0 & 10.0 & 84.0 & 16.0 \\
28 & 8.3 & 91.7 & 30.0 & 70.0 & 34.0 & 66.0 \\
30 & 8.0 & 92.0 & 8.0 & 92.0 & 36.6 & 63.4 \\
32 & 12.0 & 88.0 & 6.0 & 94.0 & 27.0 & 71.0 \\
34 & 8.2 & 91.8 & - & - & 20.0 & 80.0 \\
\hline
\end{tabular}

* Fifteen day-old culture.

** Causing damping-off of broad bean seedling. 
agar with $50 \mathrm{ppm}$ of streptomycin. The plates were incubated at $28^{\circ} \mathrm{C}$. for 24 hours. Bacterial growth was suppressed while Pythium grew considerably. Other species of fungi scarcely grew. By successive transfers of the hyphal tips to another plates or test tubes with the same medium will eventually yield a pure culture of Pythium.

The formation of reproductive organs and mycelial growth is good on decoction agar media such as corn-meal, oat-meal and potato dextrose agar but especially abundant on corn-meal agar. The optimum temperature for mycelial growth was generally from 28 to $32^{\circ} \mathrm{C}$. (Table 1 ). In relatively high temperature the formation of conidia is abundant, while oospores are formed considerably at $20^{\circ} \mathrm{C}$. (Table 2). These informations are so necessary to consider the experimental results on the formation of conidia, zoospores and oospores for morphological and taxonomic study of the Pythium.

\section{Results}

\section{Pythium spinosum Sawada}

Mycelium well developed on corn-meal agar. Hyphae irregularly branched often with few cross-walls as it become old. Sporangia are numerous in culture media and in host tissues, terminal or intercalary, spherical to oval, $8.9-23.7 \mu$ in diameter, average, $16.3 \mu$. Sporangia never produce zoospore and germinate with 1-3 germ tubes like conidia. Many oogonia are formed in culture media like conidia usually terminal and rarely intercalary, spherial, having many spines, $17.8-26.4 \mu$ in diameter, average, $22.3 \mu$. Oospores spherical, filling the oogonium, rarely not filling, $11.8-23.7 \mu$ in diameter, average, $20.0 \mu$. One or two antheridia attached to an oogonium, androgynous, usally formed from the oogonial stalk.

This fungus was isolated from diseased lotus rhizome in April, 1960, at Moriguchi City, Osaka, Japan. The fungus develops well in water where the lotus is growing and causes brownish decay of lotus rhizome tissue. At the early stage of infection the tissues were slightly brown and later become dark brown several days after infection and mycelium grew well in the holes of the rhizome. The fungus was easily isolated from the diseased tissue by using cornmeal agar containing $50 \mathrm{ppm}$ streptomycin.

This fungus is similar to Pythium mamillatum Meurs ${ }^{9)}$., $P$. echinulatum Matthews ${ }^{8)}$ and $P$. spinosum Sawada ${ }^{19)}$ due to oogonia with spines. Pythium mamillatum as has been reported podruces zoospores in sporangium and has one antheridium to an oogonium. However, because this fungus does not produce zoospore at all it is different from $P$. mamillatum. Matthews isolated Pythium echinulatum from the soil of flower bed and reported that its sporangium formed in young culture when placed in water. Thus the fungus is very similar to $P$. echinulatum. On the other hand it differs in the way of attachment of antheridia to oogonium. Pythium spinosum was isolated by Sawada from diseased seedings of Antirrhinum majus L. as a causal fungus and he described it as follows: sporangia do not produce zoospore at all; oospores are either filling or not filling the oogonium; antheridia are androgynous. These characteristics are the same as those of the fungus in question and therefore, it is identified as Pythium spinosum Sawada.

\section{Pythium ostracodes Drechsler}

Mycelium well developed on corn-meal agar and some other natural media. Hyphae irregularly branched with inflated elements. Sporangia spherical or subspherical, germinate with a long or short tube of discharge. Zoospores produced 6-15 or more to a vesicle. Conidia spherical, smooth, 23.7-30.5 $\mu$ in diameter, average, $25.0 \mu$, formed wall on maturity and germinate by a germ tube. Oogonia terminal or intercalary, spherical, smooth, 23.7-30.5 $\mu$ in diameter, average, 29.4 $\mu$. 
Oospores spherical and filling an oogonium, 21.3-29.0 $\mu$ in diameter, average, $25.5 \mu$. Antheridia filamentous with usually long crank, androgynous rarely hypogynous, arising usually from the portion far from the oogonium. One antheridium to an oogonium.

The fungus was isolated from diseased lotus rhizome in Kadoma City, Osaka, in June, 1961. The fungus develops well on several natural media as well as corn-meal agar. But the formation of oogonia on natural media is stimulated by placing the old culture of the fungus in water.

The fungus resembles Pythium graminicolum which was described as the causal fungus of root rot and sclerotial disease of gramineae by Subramanian ${ }^{20)}$. But this is not in conformity with $P$. graminicolum because zoospores are formed in spherical or subspherical sporangia.

Drechsler ${ }^{1)}$ isolated Pythium oedochilum Drech. from separate portions of decaying tissue excised from the stem and larger roots of dahlia (Dahlia rosea Cav.). The characteristics of oogonia and antheridia of the fungus resemble those of $P$. oedochilum. But the fungus differs from $P$. oedochilum in proliferous zoosporangia. The fungus looks more closely to $P$. ostracodes $D_{\text {rech }}{ }^{2}$. and perhaps resembles $P$. oedochilum Drech. and $P$. palingenes Drech ${ }^{11}$. than $P$. helicoides Drech $^{3)}$. Drechsler's description of $P$. ostracodes is as follows: sporangia spherical, oospores usually filling an oogonium, very thick oogonial wall, usually one antheridium to an oogonium, sometimes two to an oogonium, usually formed on a branch $2-100 \mu$ long arising from the same hypha.

The fungus develops well on several nutrient agar media but the sexual reproductive organs are not usually formed on these media. On corn-meal agar sexual reproductive organs are produced when the culture is submerged in water. Sporangia of the fungus are usually spherical or subspherical and oospores are generally completely filling the oogonium, rarely not filling the oogonium. From the above descriptions, the fungus does not completely fit the descriptions of $P$. ostracodes. However, many characteristics of the fungus are very alike to $P$. ostracodes. So far as the fungus in question is concerned it may be identified as $P$. ostracodes by its remarkable thick oospore wall and diagnostic antheridial features.

3. Pythium nelumbium M. Takahashi et Ouchi n. sp*.

Mycelium well developed on many common agar media and aerial mycelium grew well on corn-meal agar. Hyphae branched, $0.5-2 \mu$ in width, average, $1.2 \mu$. Sporangia filamentous, composed of inflated elements, cut-off from the remainder of mycelium by a cross-wall. Zoospores formed in a vesicle which is produced at the top of short tube discharged from the sporangium, 5-15 or more to a vesicle. Conidia formed terminal or intercalary on hyphae, spherical to oval, germinating by a germ tube. Oogonia smooth, terminal or intercalary, usually spherical, 20.7-31.1 $\mu$ in diameter, average, 27.6 $\mu$. Oospores smooth, filling the oogonium, 18.9-26.6 $\mu$ in diameter, average, $24.6 \mu$. Antheridia are remarkably characteristic chiefly because they are exceptionally numerous, rarely 3-5 and usually from 8-15 to an oogonium, crooknecked, $10-20 \mu$ in length along curved axis from apex to basal septum, borne terminally or more rarely laterally on branches arising from hypha different from those bearing oogonium, diclinous and androgynous and hypogynal.

\footnotetext{
* Mycelium hyalinum, ramosum, in hyphis $0.5-2 \mu$ latum. Zoosporangium filiforme vel irregulare inflatum. Zoosporis saepius 5-15 vel plus in vesicula evolutis. Conidium terminale vel interjunctum, globosum vel doliiforme, laeve, 20.4-30.8 $\mu$ diam. germinatum sempergermitubo. Oogonium blandus, terminale vel interjunctum, globosum, laeve, 20.7-31.1 $\mu$ diam. Oosporum inpletum in oogonium, globosum, laeve, 18.9. 26.6 $\mu$ diam. Antheridium parprima heterothallismum vel homotallismum, 8-15 antheridia haerentes ad oogonium prima laterale,3-5 antheridia raro.

Hab: Causing rhizome rot of Hindu lotus (Nelumbo nucifera Gaertn). Collected from Kadoma City, Osaka, June, 1961, by Takahashi and Ohuchi.
} 
The fungus has typical antheridia and it is very similar to $P$. arrhenomanes Drech ${ }^{4}$. and Plectospira myriandra Drech ${ }^{5)}$. Plectospira myriandra was described as a neogenus resembling Aphanomyces. But this neogenus differs from the fungus used in having inflated elements and a filamentous hyphae. $P$. arrhenomanes is closely resembling the fungus in question because of its type of antheridia and general habit. However, it differs from the present writers' fungus in having unusual filling oogonium and filamentous or lobulatous sporangia.

Sporangia of the fungus used were spherical or subspherical and its oospores were filling the oogonium. These are the characteristics which were observed only in the fungus. It is, therefore, considered that the fungus is a new species.

\section{Summary}

The rhizome rot of Hindu lotus has been reported from different parts of Japan, such as Osaka, Tokushima, Aichi and Kagawa prefectures. Several species of Pythium and Fusarium were isolated from diseased lotus rhizome and considered as the causal organisms.

Pythium species were isolated selectivery by using corn-meal agar containing 50 ppm streptomycin.

Pythium nelumbium n. sp. was identified as a new species besides $P$. spinosum Sawada, and $P$. ostracodes Drech. Sporangia of $P$. nelumbium are filamentous or composed of inflated elements and produce both zoospores and conidia. Oogonia are smooth, spherical and 20.7-31.1 $\mu$ in diameter. Oospores filling the oogonium. Numerous antheridia, 8-15, are attached to an oogonium and either diclinous or androgynous.

The fungus was isolated from diseased lotus rhizome collected from Kadoma City, Osaka. (Received November 12, 1964)

\section{Literature Cited}

1. Drechsler, C. (1941). Phytopath. $31: 478-507$.

2. Drechsler, C. (1943). ibid. $33: 261-299$.

3. Drechsler, C. (1939). ibid. $29: 391-422$.

4. Drechsler, C. (1928). ibid. $18: 873-875$.

5. Drechsler, C. (1927). J. Agr. Res. $34:$ 287-296.

6. Hori, S. (1907). Dai Nippon Nōkaihō (Trans. Agr. the Great Japan) 319:9-14.

7. Ikata, S. (1932). J. Plant Protect. $19: 11-16$.

8. Matthews, V.D. (1931). Studies on the Genus Pythium. The Univ. North Carolina Press. pp. 136.

9. Meurs, A. (1928). Wortelrot, Voroorzaakt door Schimmels uit de Geslachten Pythium Pringsheim en Aphanomycetes de Bary. Dissertation. Baarn, 94 pp. (Cited by Matthews, V.D. (1931). Studies on the Genus Pythium. The Univ. North Carolina Press).

10. Nakazawa, M. and Kato, K. (1955). Aichi-ken Nōgyō Kairyō Fukyūsho (Report Aichi Agr. Improvement \& Extension Work) $40: 9-17$.

11. Nishikado, G. and Watanabe, K. (1952). Ann. Phytopath. Soc. Japan $16: 158$.

12. Nishikado, G. and Watanabe, K, (1954). Nōgaku Kenkyū (Agr. Res.) 42 : 49-56.

13. Nishikado, G, and Watanabe, K, (1952). Ann. Phytopath. Soc. Japan $17: 38$.

14. Nishizawa, M. (1954). Bull. Kyūshū Agr. Exp. Sta. 2 : 339-348.

15. Nishizawa, M. (1954). ibid. $3: 275-280$.

16. Nishizawa, M. (1960). ibid. $6: 1-75$. 


\section{Platel 1.}

A

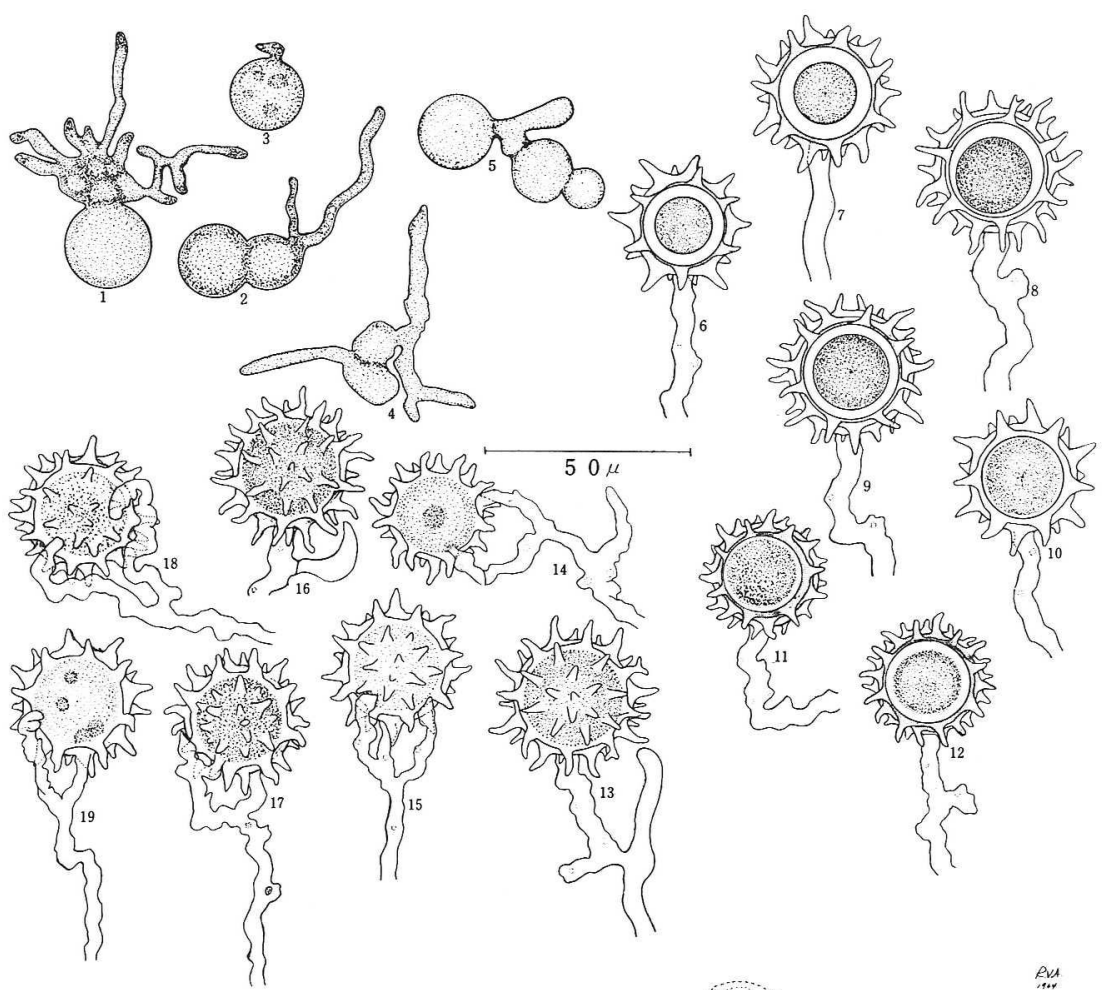

B

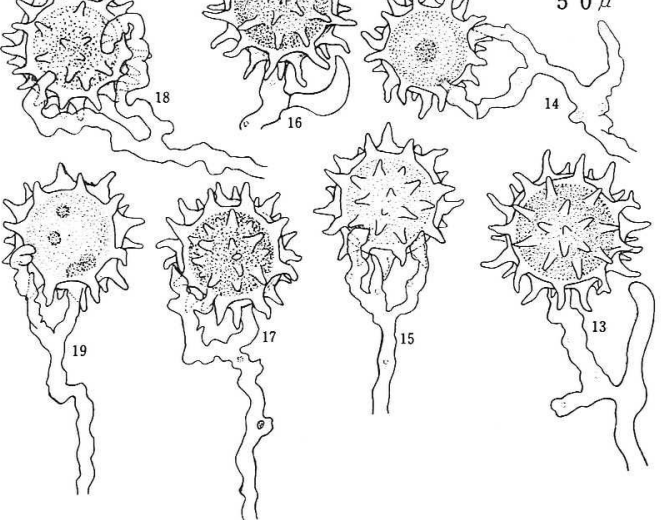

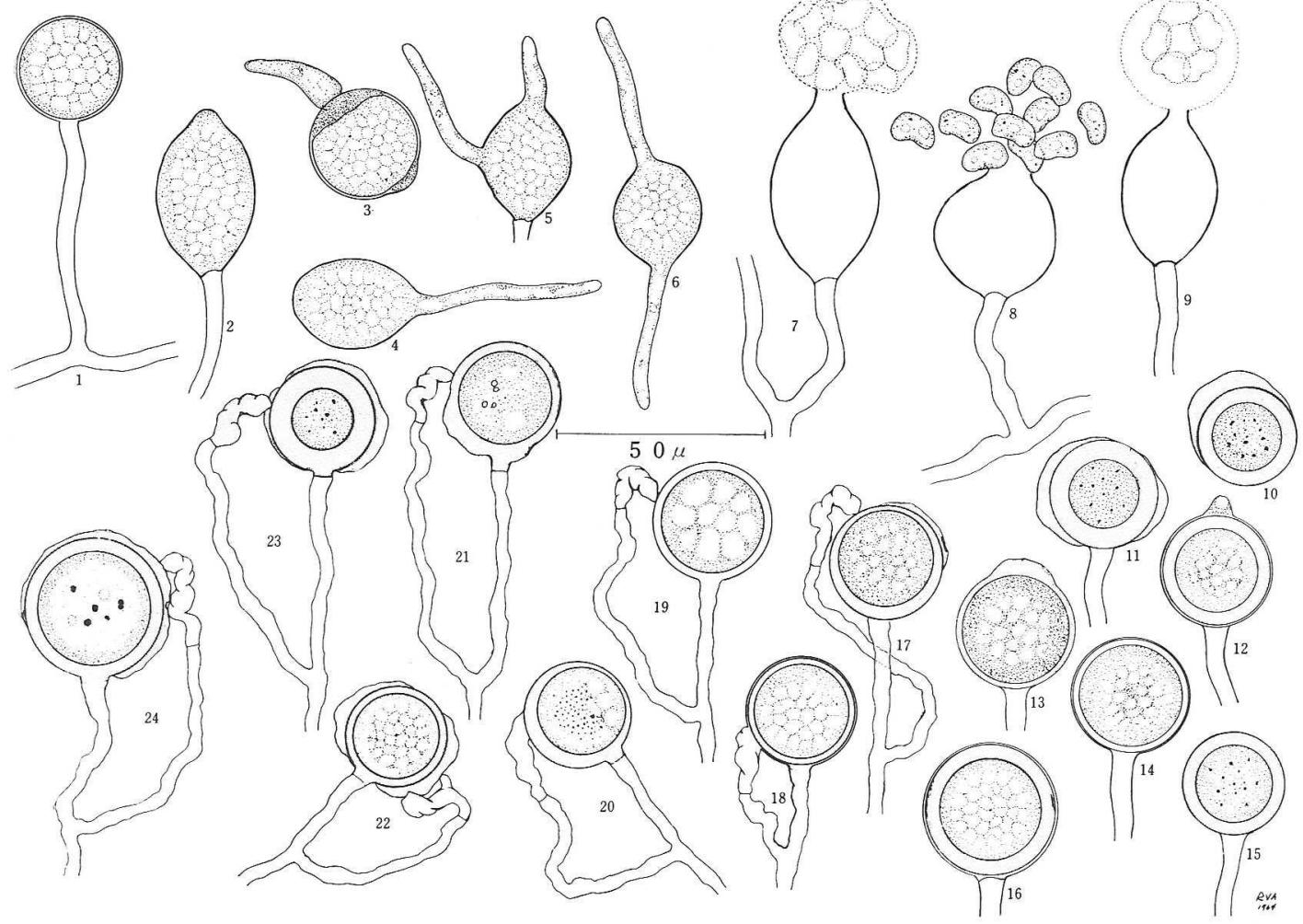


Platel 2.

C

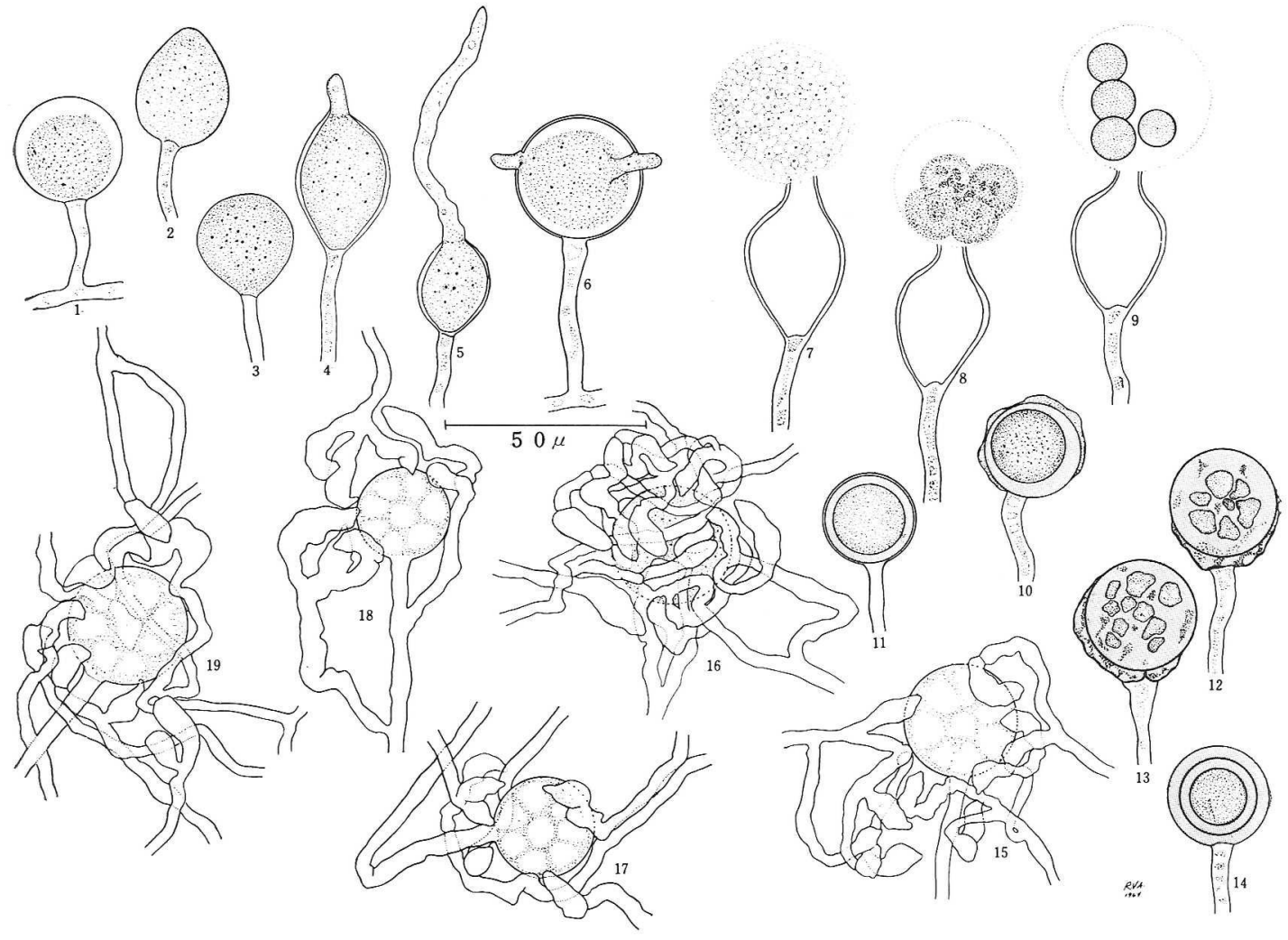


17. Okayama Nōshi Shiken Seiseki (Experimental Results Okayama Agr. Exp. Sta.). (1931, 1935).

18. Saga Nōshi Shiken Seiseki (Experimental Results Saga Agar. Exp. Sta.). (1954, 1957).

19. Sawada, K. (1927). Report Dept. Agr. Res. Inst., Formosa $27: 3$.

20. Subramanian, L.S. (1928). Agr. Res. Inst. Pusa Bull. $177: 1$.

21. Takahashi, M. and Ozaki, T. (1964). Bull. Univ. Osaka Pref. Ser. B. 17:1-10.

\title{
和交摘要
}

\author{
土壌病菌 Pythium の生態抌よび分類 \\ 第 6 報 レンコン腐敗病を原因するPythium 菌 \\ 高橋 実*.大内 昭**.R.V. AlicBUSAN***
}

大阪, 徳島, 愛知, 香川その外の各地のレンコン栽培地でレンコン腐敗病が発生している。レンコン腐敗 病菌として数種のPythium 菌とFusarium 菌が分離された。

Pythium 菌は Streptomycin $50 \mathrm{ppm}$ と PCNB $1000 \mathrm{ppm}$ で選択的に分離される。

P. spinosum Sawada, P. ostracodes Drech. の外飞新種として $P$. nelumbium n. sp. を同定した。 P. nelumbium は胞子のうが糸状めるいは脹れたのう状体で, 遊走子抽よび分生胞子を形成する。蔵卵器は 球形, 平滑, 20.7-31.1 $\mu$, 卵胞子は藏卵器内に充満する。雄精器は蔵畉器に 8-15 個着生, 異株生または 同株生である。

本菌は門真市でレンコンの腐敗病菌として分離された。

(*大阪府立大学, $* *$ 農林省農業技術研究所, ***フィリッピン大学)

\section{Explanation of plates}

Plate 1. A. Pythium spinosum Sawada

Fig. 1-5. Germinating conidia. Fig. 6-10. Mature oospores.

Fig. 11-19. Oogonia with antheridia.

Plate 1. B. Pythium ostracodes Drech.

Fig. 1-2. Conidia. Fig. 3-6. Germinating conidia.

Fig. 7-9. Sporangia germinating by zoospore formation.

Fig. 10-16. Young and mature oospores.

Fig. 17-24. Oogonia with single androgynous antheridium.

Plate 2. C. Pythium nelumbium Takahashi et Ouchi n. sp.

Fig. 1-3. Conidia. Fig. 4-6. Germinating conidia.

Fig. 7-9. Sporangia germinating by zoospore formation.

Fig. 10-14. Young and mature oospores.

Fig. 15-19. Oogonia with numerous antheridia. 